\title{
A CREDIT UNION CASE STUDY OF THE BUSINESS VALUE OF IS/IT
}

\author{
Graham Pervan and Hilangwa Maimbo \\ School of Information Systems \\ Curtin University of Technology \\ GPO Box U1987, Perth, Australia 6845 \\ Graham.Pervan@cbs.curtin.edu.au ; Hilangwa.Maimbo@standardbank.co.za
}

\begin{abstract}
This paper investigates the business value of IS/IT investments in the Financial Services Sectors (FSS) in Australia using a case study methodology to develop and refine a conceptual model of the relationship between IS/IT investment and organisational performance. The conceptual model has four main components, IS/IT investment, organisational performance, considerations for strategic information systems planning and managerial effectiveness. A case study of a credit union indicates support for components of the conceptual model. Further, the analysis reveals the existence of intermediary factors, operations, product delivery, customer service and staff. It is concluded that directing IS/IT investments to these areas, particularly when it is done in concert, is most likely to have a positive impact on organisational performance. Lastly, debate on the issue of an IS/IT investment threshold and its applicability to organisations is presented.
\end{abstract}

Keywords Information Systems, Information Technology, Investment, Organisational Performance, Case Study, Financial Services

\section{INTRODUCTION}

This article presents results from a case study that examines the relationship between Information Systems/Information Technology (IS/IT) investment and organisational performance within the Financial Services Sector (FSS) in Australia. The case study was conducted in a single medium sized Credit Union.

Financial Institutions (FIs) are heavily reliant upon IS/IT in all facets of their business, from purely operational aspects to strategic applications that are designed to gain competitive advantage and provide leverage in the market place (Apte \& Vepsalainen 1993). Consequently, FIs tend to allocate significant portions of their total capital expenditure budgets to acquiring new technologies and to maintaining existing IS/IT portfolios (Carrington, Llanguth \& Steiner 1997). As the FSS tends to be regulated (Lilja 1999), sometimes heavily, these expenditures may be discretionary (driven from within the organisation) or mandatory (required for regulatory compliance). In addition, the fact that revenues are derived from a variety of channels further complicates the IS/IT investment and organisational performance relationship. Clearly IS/IT investments are deemed to contribute to organisational performance, but how they do that and where they have the most impact remain subjects of much debate (Harker \& Zenios 2000b).

Given that total IS/IT expenditure represents a significant cost to any FI, the need for managers to understand this relationship has become increasingly important, as has the need to demonstrate that potential and existing investments in IS/IT are or will be beneficial to the organisation (Dos Santos 1991). Thus if FIs are to use IS/IT as a viable competitive weapon, their respective senior management teams (and indeed all staff) need to appreciate and understand the potential impact of IS/IT, not only on their organisations, but on the external environment as well. This in turn is complicated by the need to balance pressures to report and demonstrate good short-term financial performance against longer-term growth and investment strategies in modern FIs. Consequently some authors argue that 
IS/IT investments are benefiting consumers rather than FIs in that the efficiencies brought about by these investments create a huge opportunity cost resulting in reduced profits and shareholder returns (Carrington, Llanguth \& Steiner 1997).

Although the foregoing issues are being viewed from the perspective of FIs in particular, it should be pointed that issues relating to the business value of IS/IT in general have been the subject of much research in the past (Kivijarvi \& Saarinen 1995). Closer examination of this field of study reveals a number of themes as exemplified in Table 1. It is also well worth noting that much of this previous research appears to have been conducted in what may be considered to be less information-intensive industries such as manufacturing. Paradoxically, the FSS, which is typically regarded as a highly information-intensive industry appears to have received less attention.

\begin{tabular}{|l|l|}
\hline Theme & Sample Studies \\
\hline Effect of IS/IT at an industry level & $\begin{array}{l}\text { Sager (1988); Doll (1989); Palmer \& Markus } \\
\text { (2000); Andersen (2001) }\end{array}$ \\
\hline Performance of IS/IT department & $\begin{array}{l}\text { Borovits \& Gilardi (1993); Raghunathan, } \\
\text { Gupta \& Sundararaghavan (1989); Miller \& } \\
\text { Doyle (1987); Miller (1993); Slevin, Stieman } \\
\text { \& Boone (1991) }\end{array}$ \\
\hline $\begin{array}{l}\text { Information Systems Performance } \\
\text { and Productivity }\end{array}$ & $\begin{array}{l}\text { Scudder \& Kucic (1991); Menon, Lee \& } \\
\text { Eldenburg (2000); Floyd \& Wooldridge } \\
\text { (1990); Banker, Kauffman \& Morey (1990); } \\
\text { Panko (1991) }\end{array}$ \\
\hline IS/IT Investment and Performance & $\begin{array}{l}\text { Sethi, Hwang \& Pegels (1993); Li \& Ye } \\
\text { (1999); Weill (1992); Dos Santos, Peffers \& }\end{array}$ \\
& $\begin{array}{l}\text { Mauer (1993); Dewan, Michael \& Min (1998); } \\
\text { Thatcher \& Oliver (2001) }\end{array}$ \\
\hline IS/IT Evaluation/Value & $\begin{array}{l}\text { Tam (1998); Tam (1992); Davern \& Kauffman } \\
\text { (2000); Dos Santos (1991) }\end{array}$ \\
\hline IS/IT Benefits & $\begin{array}{l}\text { Lin \& Pervan (2003); Silk (1990); Ward, } \\
\text { Taylor \& Bond (1996); Jurison (1996) }\end{array}$ \\
\hline Realisation/Management & and studies in the business value of IS/IT \\
\hline
\end{tabular}

Table 11: Summary of research themes and studies in the business value of IS/IT literature

The rest of this article is laid out as follows: the next section reviews the IS/IT investment and organisational performance literature after which a brief overview of the Credit Union sector of the FSS in Australia is then presented. Following that the research methodology and design are discussed and the results presented after which a summary is given. Finally, some preliminary conclusions are put forward which are then followed by a discussion of the limitations and directions for further research.

\section{IS/IT INVESTMENT AND ORGANISATIONAL PERFORMANCE}

Lucas (1993) identified three main objectives for the growing interest in understanding the IS/IT investment and organisational performance relationship:

- The need to better understand how IS/IT is implemented and used

- To better understand the impact of IS/IT

- For justifying new and continued investments in IS/IT by demonstrating 
perceived benefits.

Although there have been a number of studies of this relationship over the years, careful consideration of this body of research and literature reveals three issues:

- A lack of theory (Alavi \& Carlson 1992; Gregor 2002)

- Problems with measurement (Kauffman \& Weill 1989), and,

- Lack of generalisability of results, possibly due in part to (a) and (b) (Kauffman \& Weill 1989).

\section{Theory Issues}

Kaplan and Duchon (1988) observed that the dominant approach to research in the field of MIS in general has been based on the positivist (quantitative) philosophy and that most studies measure quantitative outcomes such as technical impact, economic value, improvements in effectiveness/efficiency and financial performance. Although Lucas (1993) noted that researchers have in fact used theory from a number of fields/disciplines in an attempt to better understand this relationship (Table 2) there still appears to a lack of strong testable theory on the business value of IS/IT (Markus \& Soh 1993).

\begin{tabular}{|l|l|}
\hline Discipline & Theories \\
\hline Microeconomics & $\begin{array}{l}\text { Theory of the firm } \\
\text { Production function } \\
\text { Efficiency }\end{array}$ \\
\hline Economics & Information Economics \\
\hline Finance/Accounting & $\begin{array}{l}\text { Capital asset pricing model } \\
\text { Time value of money } \\
\text { Determination of interest rates } \\
\text { Options theory }\end{array}$ \\
\hline Behavioural science & $\begin{array}{l}\text { Organisational behaviour } \\
\text { Cognitive science }\end{array}$ \\
\hline
\end{tabular}

Table 12: Disciplines that Contribute to this Research (adapted from Lucas (1993))

Consequently, in much of this earlier research, there appears to have been a tendency to 'test' hypotheses using a variety of statistical analytical techniques applied to collected data using models derived from and developed using these contributing theories (Kauffman \& Weill 1989; Capon, Farley \& Hoenig 1990).

Markus and Soh (1993) identified and lamented the apparent lack of consensus in the IS/IT investment literature and noted the lack of theory in this field of study. Indeed, there have been many calls to build strong testable theory on the business value of IS/IT. Further, it may not be enough to simply adopt a theory from another discipline, no matter how sound, without first developing a deeper understanding of the phenomenon that is under investigation. There needs to be a structured approach to building a cumulative tradition of research into the business value of IT if we are to better understand this relationship. It is partly in recognition of this need to lay the theoretical foundations that this study utilises Case Study as the methodology (Yin 1994; Cavaye 1996) by adopting a theory development approach to build a conceptual model of this relationship. This in turn should lead to further testing of the components of the model and thus a better understanding of the business value of IT. 


\section{Methodological Problems}

Kauffman and Weill (1989) provide a well-structured review of literature in this area in which they identified a number of weaknesses in previous research;

- Equivocality on the contribution of IS/IT investments to the value/performance of organisations.

- Predominant use of statistical data analysis techniques.

- Predominance of the positivist paradigm.

- Lack of consideration of context (which is recognised as an important issue when considering performance).

- Lack of explicit consideration of actual system performance.

- Application of theory from other disciplines (economics, marketing, organisation theory etc).

- Use of different measures.

The apparent lack of a tradition of using commonly accepted measures may lead to inconsistencies in results obtained and therefore affect the generalisability of the results. While the above review only covers literature prior to 1989 , tt may be argued that this is still a definite weakness in the literature (Gregor \& Hart 2002) and there is a need to build theory by using methods such as case study.

Given the lack of consistency of reported results from previous studies, the generalisability of these results is considered low due to differences in research methods and measures employed. From a purely contextual perspective (Trauth 2001), one might also argue that both the relative differences in time periods when the studies were conducted and the locations/regions in which they were conducted would have an influence on the results obtained. In order to overcome these issues, this research project adopted and used case study methodology to develop a better understanding of the business value of IS/IT in context and so that findings may more be generalisable, thus contributing to the existing body of knowledge on this issue (Cavaye 1996).

\section{The IS/IT Investment Threshold}

It is generally agreed within the IS/IT domain that organisations need to maintain a level of expenditure in order to remain competitive (Willcocks \& Lester 1999; Harker \& Zenios 2000a). However, there appears to have been little work done in the field to determine what might be considered an appropriate level of investment. Whilst conducting research in the insurance industry, Bender (1986) observed that there appeared to be a threshold of investment in IS/IT that these organisations needed to maintain in order to remain competitive. Comparing information processing expenses with total expenditure, Bender (1986) noted from his sample of 132 companies that 22 companies had a ratio of between $5 \%$ and $10 \%, 35$ companies had a ratio of between $15 \%$ and $20 \%$ and concluded that there seemed to be an optimum level or threshold of IS/IT investment of around $20 \%$ to $25 \%$.

The establishment of such a threshold could have implications for FIs as it could be used as a benchmark by which FIs could compare their respective IS/IT expenditures. Determining such a threshold for an industry could in turn contribute significantly to the Strategic Information Systems Planning (SISP) process in that the threshold could be viewed as both an enabler when justifying expenditure relative to other FIs or a limiter when used by 
organisations to cap IS/IT expenditures.

\section{DEVELOPING THE CONCEPTUAL MODEL}

In order to better understand the business value of IS/IT, a model of this relationship, grounded in the literature, is proposed. The conceptual model suggests the existence of a relationship between the level of investment in IS/IT, as depicted by the IS/IT portfolio (Markus \& Soh 1993), and organisational performance. The model does not in any way suggest causality between the two major components. To illustrate how the model was developed, consider early models of IS investment and organisational performance. Beginning with a simple cause and effect model and using the organisation as the unit of analysis (Mckeen \& Smith 1993b), it may be argued that IS/IT investment leads to better organisational performance as shown in Figure 1.

\section{\begin{tabular}{|l|l|}
\hline IT Investment & Organisational Performance \\
\hline
\end{tabular}}

Figure 1: A simple cause and effect view of the business value of IS/IT

This view, though intuitive, is simplistic and fails to take into account the effect of factors such as the role of management, the environment and the fact that organisational performance has both an internal; and an external aspect. In addition, this view assumes that all IS/IT investment is one and the same, yet organisations invest in different types of technologies and build a portfolio of these technologies that together constitute their total technological capability. A broader perspective is therefore necessary if we are to better understand this relationship. Trice and Treacy (1986) suggested utilisation as the link between the two major components and that other factors, such as IS budgets, personnel and IS efficiency, may also influence the relationship.

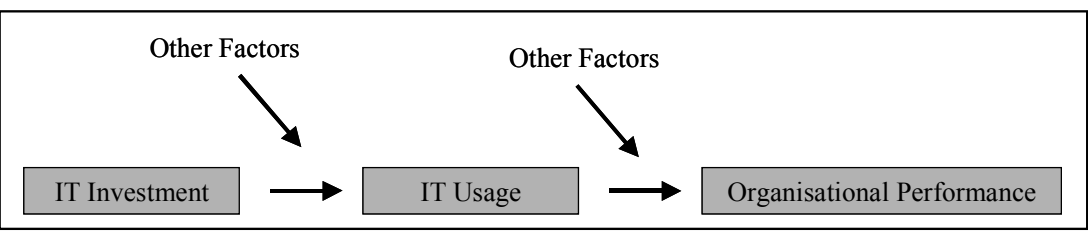

Figure 11: An expanded view of IS/IT investment and organisational performance (Trice \& Treacy 1986)

Mckeen and Smith (1993, p 625) tested this model and concluded "there is a strong linear relationship between IT investment and IT usage". Their study and its result, though encouraging, had limited generalisability due to a number of weaknesses, most notable being the fact that the study was based on a specific technology (main frames). In addition, the model is open-ended and does not suggest any form of feedback or secondary interaction between organisational performance and IT investment. This poses an interesting question, how can the investment be judged to have brought about any purported increases in performance if this secondary link is not explicitly considered? Since then, a number of models have been proposed, each being a slight variation from the theme. Some, such as Weill (1992) and Markus and Soh (1993) went further and suggested the need to 
consider the impact of different types of IS/IT investment within a given organisation and introduced the idea of the role and effect of management. Others studies suggested the need to consider the effects of time lags and the impact of learning and growth (Brynjolfsson 1993; Devaraj \& Kohli 2000).

Therefore, the proposed conceptual model of this relationship has four main components, the IS/IT portfolio (infrastructure, transaction processing and management information systems), organisational performance (internal \& external), managerial effectiveness and considerations for strategic information systems planning (Maimbo \& Pervan 2002) and organisational context.

This research was focused on the FSS in and it is proposed that the conceptual model described applies to FIs. The largest single industry within the FSS, in Australia, is the Credit Union industry. An overview of Australia's Credit Union industry now follows.

\section{CREDIT UNION INDUSTRY IN AUSTRALIA}

Crapp and Skully (1985, p1), define a Credit Union as;

"a democratically controlled voluntary co-operative society of individuals, bound together by a common bond for the pursuit of the economic welfare of members through the receipt of funds from members and other, and the provision of loans and other forms of credit and financial services to members"

The credit union movement in Australia began after the Second World War, when the credit union concept was observed in Canada by Australian Royal Air Force personnel and as a direct response to the perception that traditional banks were unresponsive to customer needs (Cooke 1989). In Australia, most credit unions are members of a larger body, Credit Union Services Corporation Australia Limited (CUSCAL), which serves as both an industry body and a service provider to its members. CUSCAL has approximately 181 member unions with a $32.45 \%$ share of the market as at the end of 2001 (WOCCU 2001). At an international level, CUSCAL is a member of the World Council of Credit Unions (WOCCU), a worldwide body that has members and affiliates around the world. With representation in over 90 countries, WOCCU represents 37,000 Credit Unions and over 112 million members (WOCCU 2003). Credit unions in Australia comprise the largest single part of the financial services sector with a combined asset base of approximately AUD \$24 billion and approximately 3.5 million members. Growth within this sector has continued to be positive and in 2001/2002 credit unions posted a combined growth of $9 \%$ (CUSCAL 2002).

Credit Unions provide a wide range of products and services including loan products, ATM access, internet banking services, credit card services and insurance. In fact, it has been noted that credit unions in Australia have been very innovative in the development of financial products and service and consequently have been noted for being the first to introduce some of the services that consumers today often take for granted. Some of these achievements include (Crapp \& Skully 1985);

- Free bill payment facilities

- Free payroll deductions facilities

- Free life insurance coverage on credit/borrowings

- First to have on-line computer operations

- First to introduce ATMs and POS

- First to introduce internationally linked ATMs and also to provide access 
to VISA's international worldwide ATM network as the first non-USA based FIs

- First to offer high interest cheque accounts

- First to offer computer based personal financial planning

- First to introduce home banking

As interest in customer service continues to grow, the issue of service quality (Duncan \& Elliot 2002) gains even more prominence. Consequently, the future for credit unions as an alternative to commercial/retail banks is strong, if they can continue to remain relevant by providing comparable or better financial services, at lower cost. For credit unions this is an area that IS/IT can provide competitive advantage if applied and utilised effectively and efficiently. For this reason, it is proposed that the conceptual model described above be investigated in credit unions and the approach to this investigation is set out below.

\section{RESEARCH METHODOLOGY AND DESIGN}

Due to the exploratory nature of the research and the need to further the development of the conceptual model, a highly structured case study methodology was chosen. Thus, recommendations from Yin (1994) and Miles and Huberman (1994) were adopted in order to address methodological issues including rigour and validity within the research project. Further, to simplify manageability of an otherwise complex research project, the research design incorporated a phased approach built around the framework proposed by Eisenhardt (1989) by grouping tasks into phases of model development, model testing and model refinement.

One of the key aspects of the research design was the development of a comprehensive Case Study Protocol (Yin 1994). This protocol outlined the procedures and rules that governed the conduct of the researchers and the research project. The case study protocol defined the type of data that would be collected, contained the research instrument used to collect data (a detailed and structured interview guide) and provided a guide for data analysis. The primary data was collected through a series of interviews with senior management involved in the IS/IT investment decision-making process.

Contact with the Credit Union case reported here was initially made informally through the Chief Executive Officer. A meeting was arranged during which the scope and objectives of the research were discussed and this was later followed up by a formal request. Once potential interviewees had been identified, interview sessions were then scheduled. All in all, four interviews were conducted, each approximately 60 - 90 minutes long, over a twoweek period. In this case, the participants were the CEO, and three department heads, MCS (Manager, Corporate Services), SMFA (Senior Manager, Finance \& Administration) and ITM (IT Manager). Each interview was recorded and when later transcribed averaged around 25 pages. In addition, a large amount secondary data in the form of internal financial data, annual reports, enterprise architecture schemas, meeting notes, strategy/planning documents, web based documents, industry statistics and other documentation/data were also collected.

The purpose of collecting such a diverse range of data facilitated the creation of a database of information on the case and enabled triangulation and convergence of information (Yin 1994) in order to get a clearer view of the issues at hand. The data were analysed using a qualitative content analysis approach that utilised a variety of techniques including inductive, deductive, comparative and pattern matching (Miles \& Huberman 1994). 
RESULTS

\section{Background}

$\mathrm{DECU}^{8}(\mathrm{Pvt})$ Ltd is a medium sized credit union operating in Australia. It has over 50000 members and a fairly widespread branch network within the metropolitan area of a state capital. Due to its size, DECU has a relatively flat organisational structure built along functional lines with the corporate head office providing administrative \& back office functions and points of representation (PORs) such as branches that act as the front office thus providing contact with customers/members.

Like most credit unions in Australia, DECU (Pvt) Ltd is a member of the Credit Union Services Corporation Australia Limited (CUSCAL) and has outsourced its central processing to Co-processing Pty Ltd, a company that runs the Integrated Data Processing Centre (IDPC). Co processing Pty Ltd was established in 1993 as a separate company owned by its founding members (credit unions) with the purpose of providing a cost effective centralised data processing environment (TSW 2003). Consequently, and by virtue of its membership, DECU enjoys both economies of scale and scope, and it is able to utilise powerful core computing services and systems that it would otherwise be unable to afford on its own. Given that DECU not only competes with other credit unions but also competes with much larger commercial/retail banks, its reliance on IS/IT is therefore significant and its ability to have access to such services critical to its existence.

DECU provides a wide range of services and products to its members including automated teller machines (ATMs), electronic funds transfer/point of sale (EFT/POS), internet banking, loans, mortgages, term deposits, savings accounts, insurance, credit cards, financial planning, share trading, estate planning, travel and many more. Over the past two years DECU has experienced a profitability growth of over $60 \%$ and much of this is has been actually attributed to previous and ongoing investments in information technology. DECU prides itself on its ability to deliver a wide range of products and services both effectively and efficiently to its members through state of the art technology.

\section{DECU's IS/IT Investment Threshold}

Figure 3 is a summary of key ratios of IS/IT investment against expenditure and revenue. As can be seen, DECU appears to have an IS/IT investment threshold of around $5 \%$. Although this figure appears to be consistent with some of the results reported by Bender (1986) and therefore encouraging with respect to establishing the concept of an IS/IT threshold, caution needs to be exercised in the interpretation of this result before any generalisations can be made. This is due to differences in research design, industry, period and region between this current study and the earlier study.

\footnotetext{
${ }^{8}$ Pseudonym, the real name has been suppressed for confidentiality reasons
} 


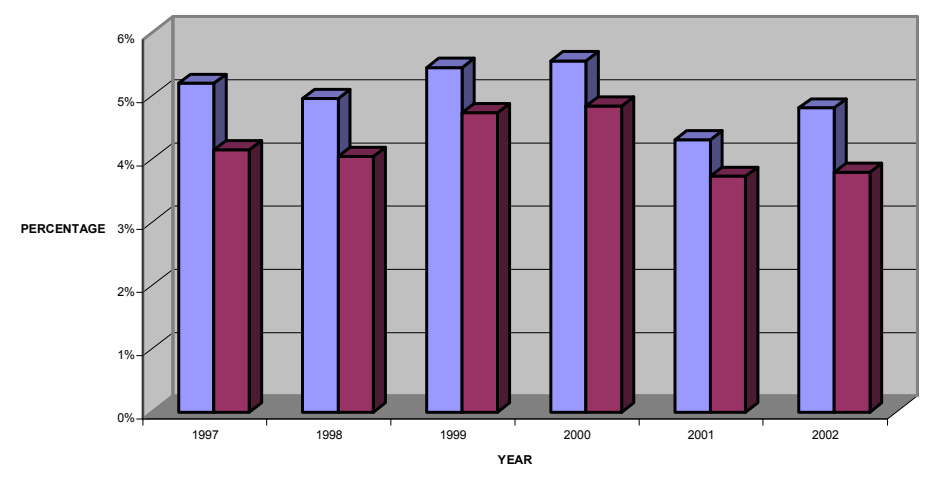

Figure 12: Key IS/IT investment ratios for DECU (Pvt) Ltd

\section{Level Of Investment (Information Systems/Technology Portfolio)}

DECU (Pvt) Ltd has a diverse IS/IT portfolio that is quite complex. In addition, DECU has a number of relationships with external third party providers as it outsources much of its IS/IT. In terms of the conceptual model, all three components of the IS/IT portfolio were observed in this organisation. One very interesting observation made during the study of this organisation were the different views (Table 3 ) of the senior management team in terms of the relative importance of the components of the IS/IT portfolio.

\begin{tabular}{|l|l|l|l|}
\hline \multirow{2}{*}{ Participant } & \multicolumn{3}{|l|}{ Ratings Of Importance } \\
\cline { 2 - 4 } & Infrastructure & Transactional & DSS/MIS \\
\hline CEO & 3 & 3 & 4 \\
\hline MCS & 5 & 5 & 2 \\
\hline SMFA & 3 & 5 & 4 \\
\hline ITM & 4 & 3 & 1 \\
\hline
\end{tabular}

Table 13: Participant ratings of relative importance of IS/IT portfolio components

These rather diverse views of the relative importance of systems that comprise the IS/IT portfolio, coupled with a rather loose definition of IS/IT by each of the participants seemed to point to the lack of a deep appreciation of the roles that each part of the IS/IT portfolio plays within the organisation. Consequently, this may lead to a lack of appropriate attention being given to components of the IS/IT portfolio when expenditure decisions need to be made. This observation was further reinforced with comments made by ITM that there was a certain element of 'scope creep' due to the lack of a more formalised definition of what constitutes IS/IT with the result that the IT function was having to take on everything that is 'technology'. Further, discussions with MCS identified the need to develop more formalised policies for the management of IS/IT, but in order to do this, more formalised definitions of what constitutes IS/IT in the organisation will be required (Frenzel 1992). Despite these apparent issues, there is a consensus that IS/IT investments as represented 
by the IS/IT portfolio are both important and critical to the organisation operation as highlighted by MCS;

"There's two things which we are, we are a retail organisation and we rely enormously on IT... if it doesn't work we have people sitting there twiddling their thumbs."

Much of DECU's investment in IS/IT has been directed at process improvement, reducing cost whilst growing the business. According to the CEO;

“...there's a lot on money to be saved on processes, our back office area has shrunk by about a tenth over the last five years while we have grown our business, probably doubled the size of our business but we've shrunk our back office"

Whilst the above may be true, and the organisation is always seeking ways to cut or maintain costs at a manageable level, it is pertinent to note that DECU, like many other Credit Unions, still has a relatively high cost to income ratio (around $80 \%$ for credit unions in general (Duncan \& Elliot 2002)). Such a high cost to income ratio may have negative implications for DECU in the following key areas:

- Customer Service - may negatively impact DECU's ability to service customers cost effectively.

- Long term profitability - Being a mutual organisation, DECU is driven primarily by member service and not profit and shareholder return

From the CEO's comments, we can see that DECU certainly views its IS/IT investment as part of its strategy to deal with the above issues. Other members of the senior management team concurred with this view and agreed that IS/IT investments to date have contributed positively to organisational performance, although as MCS put it:

"I've got a view of organisations like this that, there is very little of what we do in this organisation where you can put your finger on something and say that is the thing that makes the difference. The question is does it make a difference and I'd argue very strongly, yes, but is it $10 \%$ or $20 \%$ or $50 \%$, I would not know."

In terms of the ability of existing systems to meet the organisation's needs, we observed that although much of the DECU's infrastructure has been modernised, the core processing system is still considered to be the area that needs the most improvement primarily because of its age. According to SMFA:

"So the core system, while it is a good banking system that does everything it is supposed to do in terms of a banking system, the sort of data it produces is a little In addition: bit antiquated for what we need, particularly for things like marketing."

"Its getting a little bit cumbersome, it can't handle financial products that have become fashionable in the market."

Given the importance of core processing systems (rated higher in importance on average than the other components of the portfolio), we surmised there is a need to consider the future of these systems in the long run. Further discussion with SMFA revealed that some alternatives have been considered (through and by CUSCAL) but caution is warranted due to the significant impact that any changes would have on member Credit Unions as whole. Clearly, the need to understand the business value of IS/IT is an issue whose importance has been recognised by DECU as it strives to maximise on existing investments whilst at 
the same time planning for future investments in IS/IT.

\section{Organisational Performance}

One of the main objectives that this research aims to achieve is the identification of suitable key indicators that can be used to benchmark organisational performance in the conceptual model. Duncan and Elliot (2002), in their study of customer service and quality, identified interest margins, return on assets and capital adequacy as useful performance indicators in the FSS. Campbell (1992) suggested that organisational performance in the FSS may be best understood using what he termed the four main income drivers for banking institutions, net interest income, non interest income, operating expense and credit quality. Clearly, the diversity of performance indicators could be problematic as it makes benchmarking and comparison of organisational performance difficult (Palmer \& Markus 2000). Although it is generally accepted that most industries have commonly accepted sets of performance indicators that are used, not only for performance reporting, but also for benchmarking purposes. The caveat is that even where such indictors are used, there may still be a need to normalise them in order to ensure that they all measure the same thing. An example of such would be depreciation where different rates of depreciation may be applied which then affects the 'value' of IS/IT assets reported. This may then affect any performance ratios or indicators that incorporate this item, such as Return on Assets (ROA). The FSS is no exception in this regard. Stakeholder theory (Freeman 1984; Key 1999) provides some interesting insights and a probable explanation as to why this diversity exists.

The analysis showed the key indicators of organisational performance to be:

- Cost to Income ratio

- Return On Equity

- Interest Income

- Non-Interest Income

- Interest margins

The indicators were cross-referenced against industry statistics as reported to APRA (APRA 2003) in order to confirm their validity and suitability as organisational performance indicators for use by Credit Unions. Interesting enough, MCS suggested that organisational performance indicators might not always be considered when it came to making IS/IT related decisions. This was further corroborated by SMFA who suggested that although cost might be mitigating factor it was certainly not a limiting factor and that it was really the perceived benefits that were the deciding factor when it came to IS/IT investments. In some respects, these arguments appear to support observations in the literature regarding the difficulty of relating IS/IT investments to financial measures (Bresnahan 1986) and suggest that sometimes IS/IT investments may actually result more from qualitative assessments and even 'gut feel' or 'hunches' than anything else.

In addition to these mainly financial (external) performance indicators, our research found that DECU regularly measures its non-financial (internal) performance using surveys directed at both customers and staff. The benefits of using these management tools can be quite significant as the organisation develops a clear understanding of how it is perceived and the relevance of its products and services in the market place (Duncan \& Elliot 2002). Thus, having a clear set of indicators for organisational performance is necessary to better understand the business value of IS/IT. This may also include incorporating some qualitative measures as well. Additionally, by using a consistent set of indicators 
researchers may be better positioned to understand the business value of IS/IT (Palmer \& Markus 2000). This provides support for the organisational performance component of the conceptual model.

\section{Managerial Effectiveness}

Five factors have been identified in the literature as comprising the Managerial Effectiveness component of the conceptual model (Weill 1992; Markus \& Soh 1993). These factors were identified as:

- Senior Management commitment to IS/IT

- Experience of Organisation with IS/IT

- User Satisfaction

- Political Environment

- Organisational Structure

The research has found that the factors are present in DECU. Most striking in DECU was the degree to which DECU exhibits the first factor. DECU's senior management appear to exhibit a high level of commitment to IS/IT. Discussions with ITM provided the following comments with respect to senior management commitment, i.e.:

"Definitely absolutely, 100\%."

And:

"I think with all senior management, with all management... seeing the benefits of IT, it has to have a positive effect...I think most managers realise that IT is critical to them doing their jobs."

In fact, the CEO candidly admitted to not having a strong IS/IT background and not having been particularly in favour of IS/IT as enabler. However, he credits his change of perspective to his Second-In-Charge, MCS, whom he says has helped him to learn more about and appreciate benefits of utilising IS/IT:

"And I will be honest to say that as the CEO, I would not have had such a strong contribution from IS/IT if it wasn't for MCS and his ability to convince me to adopt this path"

By taking up the challenge to educate the CEO on the benefits of IS/IT, MCS succeeded in bridging the gap between senior management and the IS function, thus aligning their possibly divergent perspectives and in the process has facilitated the creation of an environment in which IS/IT use is encouraged through greater senior management commitment (Peppard 2001).

This willingness to learn about IS/IT, particularly at such a senior level, seems to be a strong cultural issue that senior management appears to be cultivating within the staff on the back of the realisation that most if not all of the work performed is via computers. Management therefore plays an important role in determining and encouraging the effective utilisation of IS/IT resources in the organisation. As SMFA said;

"Purely on the basis that if managers and senior managers are using the technology effectively, then everyone will use it as well. There's are a lot of things that must necessarily come from the top."

Thus, staff were actively encouraged to use computers and to learn about the various 
products and services so that they may better serve members.

One cultural issue that has been identified in the literature as having a possible negative effect was the factor relating to the political environment (Stacey 1993). DECU however did not exhibit any such negative effects. This may be related to, and mediated by, two issues, the organisational structure (factor \#5) and the apparent cohesiveness of the management team. In DECU's case, both these issues may be a direct result of the size of the organisation (Stacey 1993).

This leads to the conclusion that the impact of the Managerial Effectiveness construct on the determination of level of investment (and eventual utilisation) of IS/IT cannot be under estimated. As suggested in the literature the more effective the management process, the better the utilisation of IS/IT within an organisation (Harris \& Katz 1989; Sohal \& Ng 1998).

\section{Considerations For Strategic Information Systems Planning (SISP)}

DECU do not have any formalised process for SISP neither does it have a formal documented IS/IT strategy. According to MCS;

“...we do actually have an IT strategy, we just don't have it written down. So we've actually started to put that together."

To this the CEO adds;

"I think in reality we don't really have a strategic plan for our IT. We tend more to have a strategic plan for the business, ah and then obviously identify issues within that are relevant to the IT area."

Further enquiries revealed that DECU does instead have a structured corporate planning process through which its corporate objectives and financial targets are set. As things stand management appear to be happy with the rather informal nature of the planning process for IS/IT.

Though this approach appears to have suited DECU in the past and is currently in use, we are of the opinion that as DECU continues to grow, more structure will have to be built around the SISP process. It may be that this informal approach has already had an effect particularly on how management views the relative importance of components of DECU's IS/IT portfolio as discussed earlier. This may have important ramifications for DECU moving into to the future when it comes to determining IS/IT investment priorities (Grover, Teng \& Fiedler 1998).

\section{Organisational Context}

One of the major weaknesses identified in earlier research has been the lack of a deliberate attempt to consider the organisational context when designing research projects on the business value of IS/IT (Kauffman \& Weill 1989) although there has been a growing call for researchers to consider the issue of context in all aspects of IS research (Trauth 2001). This, in part, has led to an increased use of interpretive approaches in IS research. Organisational context is important and it is important that IS professionals and academics develop an appreciation of the organisational context in which such decisions are made in order for those decisions to be relevant. This issue of context assumes a higher level of significance for the FSS as it is a regulated industry. 
Two major organisational issues were observed. The first led to the conclusion that there are two main types of IS/IT investment decision for FIs, discretionary and mandatory. In the context of the FSS, discretionary investments are those IS/IT investments driven from within the organisation and targeted at any level of the IS/IT portfolio to achieve or deliver a given set of benefits to the organisation. Conversely, mandatory IS/IT investments as those IS/IT investments driven by the need to attain regulatory compliance as set by the industry's regulatory authority from time to time.

The second observation was that it is possible for organisations to make investments into IS/IT that may have such an impact on the environment as to change the way the organisation competes 9 . This was particularly interesting and lends support to Mcfarlan's (1984), and Porter \& Millar's (1985) views on IS/IT and competition. From that perspective, organisations may make investments into IS/IT in order to gain competitive advantage, however, the corollary to that is that IS/IT alone will not give an organisation long term competitive advantage as it can easily be duplicated (Willcocks, Feeny \& Islei 1997). Thus, IS/IT investments need to be made in the context of a broader strategy in order to achieve sustainable competitive advantage (Barua, Kriebel \& Mukhopadhyay 1991).

\section{SUMMARY}

DECU (Pvt) Ltd provided an interesting case study on the business value of IS/IT. As mentioned earlier this case is fact part of a series case studies conducted in the FSS with the aim of developing a model on the relationship between IS/IT investment and organisational performance. Consequently, we observed some new themes/factors that will enable the extension and refinement of the conceptual model.

\section{Emergent themes}

The following themes or factors were identified in the case as being those areas to which IS/IT investment is targeted and that in turn have a direct impact on organisational performance as follows;

- Operations (Alpar \& Moshe 1990)* - Banking operations relating to front office functions (points of representation) and back office functions (including head office).

- Product delivery (Carrington, Llanguth \& Steiner 1997)* - Channels through which customers access products and services.

- Customer service (DeLone \& McLean 1992)* - activities relating to the satisfying customer needs and managing relationships with customers.

- Staff (DeLone \& McLean 1992)* - ensuring that staff have adequate *Indicates support in the literature for each factor access to IS/IT resources and are able to fully utilise them.

The analysis suggests that this set forms a group of intermediary variables and leads to the conclusion that there will be some interaction between the variables themselves. Organisations that focus their IS/IT investment in these areas (in concert) are more likely to gain positive performance benefits. Further, the level of focus on each area will be different

\footnotetext{
${ }^{9}$ Specific examples cannot be provided here, as that would identify the organisation in question.
} 
for different organisations. Thus, it may be concluded that FIs will invest in an IS/IT portfolio in such a manner that they will target each of these areas for improvement with express aim of achieving improvements in organisational performance. However, at this stage causality between such IS/IT investments and organisational performance is not yet proven as much more work needs to be done in refining and testing the model.

\section{CONCLUSIONS}

Financial Institutions are by their very nature information intensive organisations (Porter \& Millar 1985). Organisations in this sector therefore present an excellent opportunity for study into the business value of IS/IT. Utilising Case Study methodology the research was conducted in a medium size credit union and the results so far indicate support for the conceptual model and its components. In addition, observations indicate the presence of a set of intermediary variables at which FIs appear to be directing IS/IT investment. Comparison with the literature has provided preliminary support for the set of intermediary variables.

Therefore, it is concluded that DECU needs to focus IS/IT investments in these areas, as that is likely to lead to performance improvements provided these investments are made in the context of a broader corporate strategy. For this to be effective, DECU needs to develop polices for IS/IT including, but not limited to, a definition of what constitutes IS/IT in DECU and who is responsible for which aspects of that IS/IT. Such policies will also ensure a common understanding of the relative importance of the different parts of the IS/IT portfolio so that IS/IT investment priorities can easily be identified. In addition, a more formalised process of SISP is recommended for DECU as the current informal process may not be sustainable as the organisation grows and competition intensifies. As part of this process, DECU will need to more carefully consider the implications of their IS/IT investment decisions by monitoring their level of IS/IT expenditure and benchmarking against competitors using performance indicators such Return on Equity (ROE), Non-Interest Income, Interest Income and Cost to Income ratio.

Limitations And Directions For Further Research

The findings for this case study are very encouraging and may lead to a better understanding of the relationship between IS/IT investment and organisational performance. However, more work still needs to be done to verify the emergent themes thereby refining and testing the conceptual model, before these results can be generalised across the FSS. As mentioned earlier, this is but one case in a broader research project involving multiple case studies and utilising a structured Case Study methodology. The findings reported here will be used for both "within case" analyses and "cross case" comparisons to and with other findings in the FSS as the research program progresses. It is hoped that this further refinement and testing will lead to a more generalisable conceptual model of the business value of IS/IT.

\section{REFERENCES}

Alavi, M. \& Carlson, P. 1992, 'A Review Of MIS Research and Disciplinary Development', Journal of Management Information Systems, vol. 8, no. 4, pp. 45-62.

Alpar, P. \& Moshe, K. 1990, 'A Microeconomic approach To The Measurement Of Information Technology Value', Journal of Management Information Systems, vol. 7, no. 2, pp. 55-69.

Andersen, T. J. 2001, 'Information Technology, Strategic Decision Making Approaches And 
Organisational Performance In Different Industrial Settings', Journal of Strategic Information Systems, no. 10, pp. $101-119$.

APRA 2003, Australian Prudential Regulatory Authority Statistics Page, Available: [http://www.apra.gov.au/] (01 July 2003).

Apte, U. M. \& Vepsalainen, A. P. J. 1993, 'High Tech or High Touch? Efficient Channel Strategies for Delivering Financial Services', Journal Of Strategic Information Systems, vol. 2 , no. 1 , pp. 39 - 54 .

Banker, R. D., Kauffman, R. J. \& Morey, R. C. 1990, 'Measuring Gains In Operational Efficiency From Information Technology: A Study Of The Positran Deployment At Hardee's Inc', Journal of Management Information Systems, vol. 7, no. 2, pp. 29-54.

Barua, A., Kriebel, C. \& Mukhopadhyay, T. 1991, 'An Economic Analysis Of Strategic Information Technology Investments', MIS Quarterly, pp. 312 - 331.

Bender, D. 1986, 'Financial Impact Of Information Processing', Journal of Management Information Systems, vol. 3, no. 2, pp. 232-238.

Borovits, I. \& Gilardi, R. 1993, 'Evaluating Cost/Utilisation Of Organisations' Information Systems And Users', Information and Management, no. 25, pp. 273 - 280.

Bresnahan, T. F. 1986, 'Measuring The Spillovers From Technical Advance: Mainframe Computers In the Financial Services.', American Economic Review, vol. 76, no. 4, pp. 742-755.

Brynjolfsson, E. 1993, 'The Productivity Paradox Of Information Technology', Communications Of The ACM, vol. 35, pp. 67-77.

Campbell, R. J. 1992, 'Does Technology Deliver?', Bankers Monthly, vol. 109, no. 3, p. 17.

Capon, N., Farley, J. U. \& Hoenig, S. 1990, 'Determinants Of Financial Performance: A Meta Analysis', Management Science, vol. 36, no. 10, pp. 1143 - 1159.

Carrington, M., Llanguth, P. \& Steiner, T. D. 1997, 'The Cost Of Technology', The Banker, vol. 147 , no. 861 , pp. 49-50.

Cavaye, A. L. M. 1996, 'Case Study Research: A Multi-Faceted Research Approach For IS', Information Systems Journal, no. 6, pp. 227-242.

Cooke, R. 1989, 'Aussie Style: Member Service And Employee Development Get Top Billing Down Under', Credit Union Management, no. August 1989, pp. 22 - 26.

Crapp, H. \& Skully, M. T. 1985, Credit Unions For Australians, George Allen and Unwin Australia Pty Ltd, North Sydney.

CUSCAL 2002, Annual Report 2002, Credit Union Services Corporation Australia Limited.

Davern, M. J. \& Kauffman, R. J. 2000, 'Discovering Potential And Realised Value From Information Technology Investments', Journal of Management Information Systems, vol. 16 , no. 4 , pp. $121-143$.

DeLone, W. H. \& McLean, E. R. 1992, 'Information Systems Success: The Quest For The Dependent Variable', Information Systems Research, vol. 3, no. 1, pp. 60-95.

Devaraj, S. \& Kohli, R. 2000, 'Information Technology Payoff In The Health-Care Industry: A Longitudinal Study', Journal of Management Information Systems, vol. 16, no. 4, pp. 41 $-67$.

Dewan, S., Michael, S. C. \& Min, C.-K. 1998, 'Firm Characteristics And Investments In Information Technology: Scale And Scope Effects', Information Systems Research, vol. 9, no. 3, pp. 219 - 232.

Doll, W. J. 1989, 'Information Technology's Strategic Impact On The American Air Travel Service Industry', Information and Management, no. 16, pp. 269 - 275.

Dos Santos, B. L. 1991, 'Justifying Investments In New Information Technologies', Journal of Management Information Systems, vol. 7, no. 4, pp. 71-90. 
Dos Santos, B. L., Peffers, K. \& Mauer, D. C. 1993, 'The Impact Of Information Technology Investment Announcements On The Maket Value Of The Firm', Information Systems Research, vol. 4, no. 1, pp. 1 - 23.

Duncan, E. \& Elliot, G. 2002, 'Customer Service And Financial Performance Among Australian Retail Financial Institutions', Journal Of Financial Services Marketing, vol. 7, no. 1 , pp. $25-41$

Eisenhardt, K. M. 1989, 'Building Theories From Case Study Research', Academy Of Management Review, vol. 14, no. 4, pp. 532 - 550.

Floyd, S. W. \& Wooldridge, B. 1990, 'Path Analysis Of The Relationship Between Competitive Strategy, Information Technology, And Financial Performance', Journal of Management Information Systems, vol. 7, no. 1, pp. 48-64.

Freeman, R. 1984, Strategic Management: A Stakeholder Approach, Ballinger, Boston, MA.

Frenzel, C. W. 1992, Management Of Information Technology, Boyd And Fraser, Boston, $\mathrm{Ma}$

Gregor, S. 2002, 'A Theory Of Theories In Information Systems', in Information Systems Foundations: Building The Theoretical Base Workshop, eds. Gregor, S. \& Hart, D., School Of Business And Information Management, Australia National University, Australia National University, Canberra.

Gregor, S. \& Hart, D. (eds.) 2002, Information Systems Foundations: Building The Theoretical Base, School Of Business And Information Management, Australia National University, Canberra.

Grover, V., Teng, J. T. C. \& Fiedler, K. D. 1998, 'IS Investment Priorities In Contemporary Organisations', Communications Of The ACM, vol. 41, no. 2, pp. 40 - 48.

Harker, P. T. \& Zenios, S. A. (eds.) 2000a, Performance Of Financial Institutions, Cambridge University Press, New York.

Harker, P. T. \& Zenios, S. A. 2000b, 'What Drives The Performance Of Financial Institutions?', in Performance Of Financial Institutions, eds. Harker, P. T. \& Zenios, S. A., Cambridge University Press, New York, pp. 3-31.

Harris, S. E. \& Katz, J. L. 1989, 'Predicting Organisational Performance Using Information Technology Managerial Control Ratios', in Proceedings Of The 22nd Annual Hawaii International Conference on Systems Sciences, Cambridge University Press, New York, pp. 197-204.

Jurison, J. 1996, 'Toward More Effective Management Of Information Technology Benefits', Journal of Strategic Information Systems, no. 5, pp. 263 - 274.

Kaplan, B. \& Duchon, D. 1988, 'Combining Qualitative and Quantitative Methods In Information Systems Research', MIS Quarterly, pp. 571-586.

Kauffman, R. J. \& Weill, P. 1989, 'An Evaluative Framework For Research On The Performance Effects Of Information Technology Investment', in Proceedings Of The Tenth International Conference On Information Systems, Boston MA, ButterworthHeinemann, 313 Washington St, Newton, MA, Newton, MA, pp. 377-388.

Key, S. 1999, 'Toward A new Theory Of The Firm: A Critique Of Stakeholder 'Theory", Management Decision, vol. 37, no. 4.

Kivijarvi, H. \& Saarinen, T. 1995, 'Investment In Information Systems And Financial Performance Of The Firm', Information And Management, no. 28, pp. 143 - 163.

Li, M. \& Ye, R. 1999, 'Information Technology And Firm Performance: Linking With Environmental, Strategic And Managerial Contexts', Information And Management, no. 35 , pp. $43-51$. 
Lilja, P. 1999, 'Structural Changes In The Banking Sector- Driving Forces And Consequences', Quartely review - Sveriges Riksbank, no. 4, pp. 43-63.

Lin, C. \& Pervan, G. 2003, 'A Public Sector Case Study On Evaluating and Managing the Benefits IS/IT', in Technologies and Methodologies for Evaluating Information Technology In Business, ed. Davis, C. K., Group Publishing, Hershey, USA.

Lucas H. C. Jr., 1993, 'The Business Value Of Information Technology: A Historical Perspective And Thoughts For Future Research', in Strategic Information Technology Management: Perspectives On Organisational Growth And Competitive Advantage, eds. Banker, R. D., Kauffman, R. J. \& Mahmood, M. A., Idea Group Publishing, Harrisburg, PA, pp. 359-374.

Maimbo, H. \& Pervan, G. 2002, 'A Model Of IS/IT Investment in The Banking Industry', in Ninth European Conference On Information Technology Evaluation, eds. Brown, A. \& Remenyi, D. S. J., Universite Paris - Dauphine, France, 15 - 16 July.

Markus, L. M. \& Soh, C. 1993, 'Banking On Information Technology: Converting IT Spending Into Firm Performance', in Strategic Information Technology Management: Perspectives On Organisational Growth and Competitive Advantage, eds. Banker, R. D., Kauffman, R. J. \& Mahmood, M. A., Idea Group Publishing, Harrisburg, PA, pp. 375 403.

Mcfarlan, F. W. 1984, 'Information Technology Changes The Way You Compete', Harvard Business Review, vol. May-June 1984.

Mckeen, J. D. \& Smith, H. A. 1993a, 'Linking Investment With IT Usage'.

Mckeen, J. D. \& Smith, H. A. 1993b, 'The Relationship Between Information Technology Use And Organisational Performance', in Strategic Information Technology Management: Perspectives On Organisational Growth and Competitive Advantage, eds. Banker, R. D., Kauffman, R. J. \& Mahmood, M. A., Idea Group Publishing, Harrisburg, PA.

Menon, N. M., Lee, B. \& Eldenburg, L. 2000, 'Productivity Of Information Systems In the Healthcare Industry', Information Systems Research, vol. 11, no. 1, pp. 83 - 92.

Miles, M. B. \& Huberman, A. M. 1994, Qualitative Data Analysis: An Expanded Source Book, 2nd edn, Sage Publications Inc., California.

Miller, J. 1993, 'Measuring And Aligning Information Systems With The Organisation', Information and Management, no. 25, pp. $217-228$.

Miller, J. \& Doyle, B. A. 1987, 'Measuring The Effectiveness Of Computer Based Information Systems In The Financial Services Sector', MIS Quarterly, pp. 106 - 124.

Palmer, J. \& Markus, L. M. 2000, 'The Performance Impacts Of Quick Response Strategic Alignment In Specialty Retailing', Information Systems Research, vol. 11, no. 3, pp. 241 $-259$

Panko, R. R. 1991, 'Is Office Productivity Stagnant?', MIS Quarterly, pp. 191 - 203.

Peppard, J. 2001, 'Bridging The Gap Between The IS Organisaiton And The Rest Of The Business: Plotting a Route', Journal Of Information Systems, no. 11, pp. 249 - 270.

Porter, M. E. \& Millar, V. E. 1985, 'How Information Gives You Competitive Advantage', Harvard Business Review, vol. 63, no. July - August, pp. 149 - 160.

Raghunathan, T. S., Gupta, Y. \& Sundararaghavan, P. S. 1989, 'Assessing The Impact Of IS Executives' Critical Sucess Factors On The Performance Of IS Organisations', Information and Management, no. 17, pp. 157 - 168.

Sager, M. T. 1988, 'Competitive Information Systems In Australian Banking', Information and Management, no. 15, pp. 59 - 67.

Scudder, R. A. \& Kucic, A. R. 1991, 'Productivity Measures For Information Systems', Information and Management, no. 20, pp. 343 - 354. 
Sethi, V., Hwang, K. T. \& Pegels, C. 1993, 'Information Technology And Organisational Performance', Information and Management, no. 25, pp. 193-205.

Silk, D. J. 1990, 'Managing IS Benefits For The 1990s', Journal Of Information Technology, no. 5 , pp. $185-193$.

Slevin, D. P., Stieman, P. A. \& Boone, L., W. 1991, 'Critical Success Factor Analysis For Information Systems Performance Measurement And Enhancement', Information and Management, no. 21, pp. 161 - 174.

Sohal, A. S. \& Ng, L. 1998, 'The Role And Impact Of Information Technology In Australian Business', Journal of Information Technology, no. 13, pp. 201-217.

Stacey, R. D. 1993, Strategic Management And Organisational Dynamics, Pitman Publishing, London.

Tam, K. Y. 1992, 'Capital budgeting In Information Systems Development', Information And Management, no. 23, pp. 345 - 357.

Tam, K. Y. 1998, 'The Impact Of Information Technology Investments On Firm Performance And Evaluation: Evidence From Newly Industrialised Economies', Information Systems Research, vol. 9, no. 1, pp. 85-98.

Thatcher, M. E. \& Oliver, J. R. 2001, 'The Impact Of Technology Investments On A Firm's Production Efficiency, Product Quality And Productivity', Journal of Management Information Systems, vol. 18, no. 2, pp. $17-45$.

Trauth, E. M. 2001, 'The Pursuit Of Information Technology In Context', in Australasian Conference On Information Systems, eds. Finnie, G., Cecez-Kecmanovic, D. \& Lo, B., Coff's Habour, NSW, Australia.

Trice, A. W. \& Treacy, M. E. 1986, 'Utilisation As A Dependent Variable In MIS Research', in Proceedings Of The Seventh International Conference On Information Systems.

TSW 2003, Co-processing Pty Ltd, Available: [http://www.copro.com.au/overview.html] (29 May 2003).

Ward, J., Taylor, P. \& Bond, P. 1996, 'Evaluation And Realistion Of IS/IT Benefits: An Empirical Study Of Current Practice', European Journal Of Information Systems, vol. 4, pp. $214-225$.

Weill, P. 1992, 'The Relationship Between Investment In Information Technology And Firm Performance: A Study Of The Valve Manufacturing Sector', Information Systems Research, vol. 3, no. 4, pp. 301-332.

Willcocks, L., Feeny, D. \& Islei, G. 1997, Managing IT As A Strategic Resource, McGrawHill International (UK) Ltd, Berkshire, England.

Willcocks, L. \& Lester, S. 1999, Beyond The Productivity Paradox, John Wiley And Sons, Chichester, UK.

WOCCU 2001, 2001 Statistical Report, World Council Of Credit Unions Inc.

WOCCU 2003, WOCCU members, Available: [http://www.woccu.org/about/memlist.htm] (29 May 2003)

Yin, R. K. 1994, Case Study Research: Design and Methods, 2nd edn, Sage Publications Inc, Thousand Oaks, California. 